\title{
Surfaces
}

\section{Memoir: In Celebration of Academic and Athletic Excellence}

\section{Stephen Melville}

Volume 6, 1996

LES ÉCONOMIES DISCURSIVES DU SAVOIR ET DE LA CULTURE DANS LE SILLAGE DE L'OEUVRE DE BILL READINGS

THE DISCURSIVE ECONOMIES OF KNOWLEDGE AND CULTURE, WITH CONSTANT REFERENCE TO THE WORK OF BILL READINGS

URI : https://id.erudit.org/iderudit/1064850ar

DOI : https://doi.org/10.7202/1064850ar

Aller au sommaire du numéro

Éditeur(s)

Les Presses de l’Université de Montréal

ISSN

1188-2492 (imprimé)

1200-5320 (numérique)

Découvrir la revue

Citer cet article

Melville, S. (1996). Memoir: In Celebration of Academic and Athletic Excellence. Surfaces, 6. https://doi.org/10.7202/1064850ar
Résumé de l'article

Pensées et souvenirs autour de Bill Readings, du changement dans le curriculum et des éléments sportifs.
Copyright @ Stephen Melville, 1996

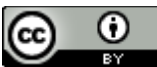

Ce document est protégé par la loi sur le droit d'auteur. L'utilisation des services d'Érudit (y compris la reproduction) est assujettie à sa politique d'utilisation que vous pouvez consulter en ligne.

https://apropos.erudit.org/fr/usagers/politique-dutilisation/ 


\section{Memoir: In Celebration of Academic and Athletic Excellence}

Stephen Melville

History of Art

Ohio State University

Surfaces Vol. VI. 205 (v.1.0A - 09/09/1996) - ISSN:

1188-2492

Copyright for texts published in Surfaces remains the property of authors. However, any further publication should be accompanied by an acknowledgement of Surfaces as the place of initial publication.

\section{ABSTRACT}

Thoughts on, and memories of, Bill Readings, curricular change, and the elements of sport.

\section{RÉSUMÉ}

Pensées et souvenirs autour de Bill Readings, du changement dans le curriculum et des éléments sportifs

"Saxophone Grammaticus," very nearly named "All Nite Brit-O-Mart," cannot be said to have had a glorious history, but we did get better and we certainly had fun. Improving is, of course, relatively easy when you start with things like a cricket-playing left-fielder who throws the ball triumphantly up in the air after taking a catch, allowing two further runs to score. We made the play-offs a couple of times and at least knew that if we lost, it could usually be traced to our own stupidity and failure. 
For the most part, when somebody wasn't hitting, somebody else was, and we had a pitcher and a string of shortstops who made up for a lot. Playing in a student league, we always had our age to fall back on in defeat, our cunning in victory. And there was always theory to help make it all right: we'd retreat to Bill and Diane's deck with beer and pizza and talk for hours about whatever, although the talk would keep circling back through that afternoon's particular round of injustices and blunders, until late in the evening, the beer having given way to whiskey, Bill would announce, "If you really think about it, we won." This would be followed by a relatively arcane exercise in redescription and close reasoning that could not exactly be called persuasive-the score was, after all, unbudgeable-but could nonetheless be properly described as marvellously compelling. Which was all it needed to be. These were, no doubt, our most fully theoretical moments. We had, now that I think about it, a terrific record.

I started at Syracuse University as an assistant professor in the fall of 1982. The age of the department was such that this marked the beginning of a fairly sustained cycle of junior hiring: Linda Shires came in the year before me, the following year brought Bennet Schaber, then Bill, then Veronica Kelly, Tom Yingling, and Robyn Wiegman. I may be getting the order of things slightly wrong here and am certainly omitting some people and minor complexities in the actual hiring processes, but the general point is, I hope, clear enough: Syracuse was able in a time of general job shortages to do a considerable amount of hiring and, because the large cohort of associate professors had recently become convinced of the value of "theory," the department expected (and found) a fair degree of theoretical sophistication in those it hired. This general hiring direction had the approval of the dean of the College of Arts and Sciences, who was interested in the department's "being put on the map" and persuaded that theory was the way to do this.

When I first arrived at Syracuse, the deeply divided department had evidently given up on the idea of welcoming parties for new faculty. A few people had us over for dinner, and later I was granted an audience with the resident Eminent Theorist, who wished to determine if it was possible to open a discourse with me. I didn't do very well at that interview or at its sequels; he was particularly wary of my tendency to associate theory, and intellectual life more generally, with food and drink. Later, new faculty tended to throw their own welcoming parties, and Steve Mailloux always threw a fall welcome. 
But somewhere along the line, newly hired faculty making summer house-hunting trips also started being dragged by one or another person to a Sax Gram game or practice.

One of my first days at Syracuse, a senior faculty member sat down next to me on the quad where I was eating my lunch and asked if I played tennis. When I allowed as I didn't, he said, as nearly as I can recall, "That's too bad. I was hoping they'd hired a human." Probably the longest conversation the two of us had during my nine years there.

I suppose the point here is that Sax Gram had a certain relation to something one might as well call civility, and if at the time my tennis-playing colleague merely struck me as less than civil, it strikes me in retrospect that perhaps he should have been recognized as in search, however oddly, of something like civility.

Sax Gram certainly had its own weird bits of etiquette, and people who couldn't master those bits soon left the team.

The department that was graced with this influx of new personnel had, of course, its own peculiar history-one that had resulted in a small and relatively weak group of faculty approaching retirement age, and a distinct second generation of professionally ambitious faculty members hired in the early to mid-seventies and thus forming a distinct mid-level in the department. Many of these faculty had been strongly influenced by Mas'ud Zavarzadeh, whose version of Marxism did much to shape their general notion of theory-a notion of theory not wholly shared by the new hires. But as long as one spoke only in general terms of "theory," it seemed clear that the majority of the department favored moving ever more firmly in that direction, and when the department found itself obliged to look outside for a new chair, it became an explicit part of that search that the new chair would be expected to oversee the construction of a new, theoretically ordered curriculum. As a result of that search, Steven Mailloux was hired as chair, and full scale curricular discussions began in earnest.

Some features of this general situation are worth remarking. Although in the build-up to the curricular discussions, things tended to be cast in terms of some opposition between "traditional literary study" and "theory," there was never any serious question about which way the department was going to go-the numbers had already decided that-and there was no serious 
defense of traditional literary study offered within the discussions because the faculty in question were largely unable to mount such a defense, which is to say that they did not understand, or were unable or unwilling to articulate, the ground of their own activity. If their position was to be registered at all, it would have to be ventriloquized from elsewhere in the departmentsomething that did happen to some degree as the debates unfolded. The absence of any strongly held "traditional" position within the department was damaging to the actual course of the discussions, but it also called out in interesting ways for diagnosis, something of which I take to be reflected in Bill's later willingness to review the history of the university and its presiding ideas. While this absence was in part a symptom of the weakness of the most senior layer of the faculty, it also represented a differend of sorts between a group of faculty whose notion of theory was predicated on a professionalism that was already alien to the "traditional" group and in the face of which that group was, to a high degree, unable to speak, unable to make itself heard. If one gives this fact full weight, then there are two narratives intertwined from the beginning at Syracuse: one that sees whatever happened there unfolding as result of the conflict within literary study between traditional and newer, theoretically informed approaches, and another that sees those same events in terms of a deeper conflict between a silenced past of the university and a present in which administrative interests and a newly professionalized faculty worked together on grounds rendered usefully opaque by the invocation of "theory."

And, of course, it was this invocation that was really at issue and formed the center of the visible debates. In personal and institutional terms, the sides were clear enough. Various characterizations attempted to capture the division within the theorists: political vs. apolitical, Marxist vs. non-Marxist, cultural studies vs. something that still wanted to speak of literature, "theory" in some strong sense vs. "reading"-the familiar coin of contemporary theoretical polemic. Somewhere in the middle of this is the less familiar, practical opposition that might be cast as truth vs. sociability, as measured by a willingness to play real softball as against the imaginary hardball of departmental politics.

It seems to me now that perhaps the best characterization would be in terms of a struggle over the ruins of what Bill came to call the University of Culture. If that university could see its central object naturally divided between the humanities and the social sciences 
(surely that university's most salient fact), the question was whether the collapse of the humanities as conceived in that university meant, in effect, that its former domain was to be turned over to the social sciences or whether the form of its breakup entailed an assault on the social sciences drawing upon some as yet unapprehended resource more or less continuous with the ruin of the university. This is to suggest that in the breakup of the university of culture the social sciences play the role of hinge between the older universities of rationality and of culture and the new administrative university in which they collectively enter a strong and successful claim to be the knowledge that assigns the university its proper shape.

To the extent that a faculty accepts these sciences' collective description of its activity-as, for example, a professional activity oriented at the forming of further members of the profession-it already accepts the professionalizing description of the university and vacates in advance any possibility of defending or justifying its activity in other terms. In terms of the kind of curricular debate that went on at Syracuse, this means that there is an inner knotting of professionalism, administration, and social science that will determine what and how "theory" can mean unless the discussion finds some way to cut through it. At Syracuse, we did not find a way, and the more or less inevitable result was that the curriculum we constructed simply mapped a certain professional self-apprehension and equally simply imagined its work in terms of the reproduction of that profession (however much the language of the debate posed this in terms of the production of critical cultural agents). In the end, "theory" functioned above all as a powerful accelerator to further professionalization and separation, as well as to the assimilation of the traditional humanities to the social sciences. This can strike one as an extraordinary outcome: theory-the work of Derrida, Foucault, Lacan, Lyotard, and others-is, after all and among other things, a massive critique of the social sciences; that it may be irreceivable as such would be testimony to the strength of the institutional formation that dictates the terms of its reception.

Sax Gram was where those who were not willing to reduce themselves to curricular positions played out an important part of their game. It was, I suggest, as close as the English Department came in a loose political analogy to civil society, and if it did in some measure represent a shared curricular position, that position was 
that the work of education could not simply be sealed in a curriculum--any more than a society can be constructed simply out of individuals and some overarching political coordination of their positions. It was where myth and tradition and everything that resists administered social order, even self-administered, went.

No doubt there are those whose stories of curricular change in the department would include some passing mention of a kind of softball cabal, as if Sax Gram stood for some particular position in the department's battles. That's not in any simple way wrong. But it's a way of absorbing the softball team into the world of professional self-understanding - a world in which the object was for everyone's position to be variously charted, defended, interrogated, or critiqued. Whereas Sax Gram's actual place in those wars was to be (almost) outside them, to insist on the priority or at least on the necessity of an arena in which one's address was either not known or was fixed by some entirely other logic. In the absence of this other arena, everything at Syracuse would no doubt have still come to the same conclusion, the same curriculum would have been produced. There was, after all, a certain fatality in our fall toward simply reproducing the map of the profession as the department's members understood and represented it; we ended by organizing our curriculum around the terms politics, history, and theory - terms that, appropriately Latinized, reappeared on our team shirts. Sax Gram, both a cause and an effect of this curriculum, mattered, if it did at all, as a modulation or inflection of the process - perhaps as an attempt to register or install something other than the curriculum within or alongside it.

There were during the discussions at Syracuse some interesting moments of resistance to the eventual outcome. Steve Mailloux arrived offering a vision of a department structured around the three terms rhetoric, culture, and theory. Since rhetoric had no particular history or purchase in the department, Mailloux's hope was that its ability to link the literary or textual and composition sides of the department would justify the place he proposed for it. However, the Writing Program, set toward its own theoretical and institutional autonomy, never fully entered into the discussion, and so Mailloux's imagination of "Cultural Rhetoric" never found an adequate hold.

So we worked with the mere form of the triangle that was left; its arbitrariness seemed good enough to dream on and around, and some of us imagined that if we could work it right, we would discover ourselves distributed by 
it in some new way. Bennet Schaber proved particularly adept at working it in these terms, proposing early on a Lacanian reading in which its sides were to be understood as limning the impossible shape of a lost disciplinary object. This was the single most powerful curricular proposal our discussions generated, and it was quickly swamped by all those who imagined we could produce students who would know the truth. I like to think it finds new life in Bill's notion of a university in ruins-although Bill himself could only reluctantly be drawn into discussions of disciplinarity and objectivity.

Bennet's strong Lacanianism also let him understand that a curriculum was not so much a way, as many in the department wanted it to be, of producing something ("new knowledge," "agents of cultural critique," etc.), as it was a way of articulating the conditions of speaking to which we would then be obliged. And he understood as well that it was the standard against which our teaching (teaching that was, then, inherently departmental rather than individual) was to be measured. The implicit model here was la passe--the entry into l'école predicated on one's ability to make one's experience communicable as theory. One may have (Bill had, I perhaps have) good reasons not to rest with these Lacanian analogies, but they seem also, as Derrida says of Heidegger, incontournables, definitively shifting the ground in ways that can only be clear when they have been fully explored. For example: what difference might it make to how we take Bill's invocation of "the time of the student," if we try to be explicit about its affinities with Lacan's temps logique?

As our coach, Bennet was nothing if not intimate with despair. One year we almost made it into the finals. Down one, bottom of the tenth, one out, and a runner on third: the batter delivers an appropriately long drive to deep left field; the runner leaves too early, and, with all of us first cheering and then shrieking, starts back to tag up, falls and then tries to crawl on her hands and knees back to third. As her hand reaches toward the bag, the ball arrives, completing the double play and ending the season. And in the sudden silence there was only Bennet on the sidelines, yelling, "I hate this team! I hate this team!"

We were very fond of being hated by Bennet. No one else would have put up with us, and it helped that he couldn't keep, in a pinch, being as stupid as the rest of us: he had the hands, brain, and quickness to play short but in 
moments of excitement regularly hurled the ball over the first baseman and into unmapped territory.

Ohio State University, where I currently teach, keeps up a pretty steady drumbeat around "quality" and "excellence" as it restructures and develops various new ties with Ford, Kellogg, and the like. An interesting thing about Syracuse was that it kept inserting an extra little hitch into its attempts at this rhythm, regularly substituting "perceived excellence" for "excellence." This presumably reflects a desire to have things both ways: Syracuse is excellent and needs no improvement-except that there is always room for improvement of perception. But of course it also simply speaks the truth of "excellence" in its sheer formalism and empty selfreference. (Syracuse was perhaps peculiarly prone to this kind of formulation: trying to damp down the substantial student drinking, it came up with the slogan "S.U. Drinks Sensibly," which, reduced to the acronym SUDS, was distributed on buttons featuring a foaming beer mug.)

The push toward "perceived excellence" resulted in a number of other initiatives outside the English Department with which some of us found ourselves repeatedly involved. One was what seemed like a continuous series of reviews and revisions of the interdisciplinary graduate program in the Humanities-a series driven by the repeated conclusion that the program could be nothing without serious faculty and graduate student resources, the administrative rejection of that conclusion, and the request to start again. Another was a multiyear Mellon-financed effort to rethink "the integration of liberal and professional education."

The first of these-somewhat like the Vision and Textuality lecture series Bill and I put together-kept in view a question about the limits of what we were trying to do in the English Department and so offered a staging ground for questions of disciplinarity; that this was a fairly weak and frustrated ground for such questions has some relation both to the way in which exploring implications of theory remained confined to questions of departmental curriculum and to the subsequent desire to shift the question from department to university.

The Mellon project remained pretty peripheral to departmental debates. For the most part its work (which resulted in a handful of courses that the university took no further interest in once the funding was exhausted) varied between blandness and frustration, but there 
were threads of excitment that ran through it-one linked to its recognition of the thoroughgoing professionalism of the contemporary liberal arts, another linked to an uneasily and uncertainly shared sense that the work of education ought to constitute some form of resistance to this-and it did generate one particular notion, of "teaching in one another's light," that Bill (who was not part of the Mellon project) took up and transformed in his imagination of the university as a place where thought takes place beside thought.

It seems to me important about the team that it was never quite the Syracuse University English Department team. Mostly it was, but there were always a couple of people from somewhere else--lovers, friends of friends, people who just sort of appeared and hung on, people from less athletic (or less competitive, or less sociable, or less something) departments. And, of course, the team never represented more than some fraction of the full membership of the department. A couple of years ago I had to return to Syracuse for a dissertation defense, and at some point late in the evening's celebration, we realized that everyone left in the room had played for Sax Gram. It would be nice to say that this particular roomful of people felt like "the real department." But it is important that it wasn't quite, that it was just a group of people who had found a way to take pleasure in-and do work by-playing in the ruins to which the identity and bearing of that work and pleasure remained obscurely bound. And it may also be important that this was already a moment of repetition, distilling (like these notes) a particular and partial version of Saxophone Grammaticus out of its dispersion.

Thinking back now to what Syracuse was at its best (and thinking back, before that, to what the University of Chicago was for me as a student), I find a community-of dissensus, if you wish-above all committed to making thought matter. I mean this last phrase in way that rhymes with "taking thought as matter," so that what may be palpable in it is the way in which thought is tied to dissensus just because what thought does is matter (what it does, it does as matter). That thought matters remains, I believe, the strange, difficult, necessary, and familiar thought at the heart of the university, and it is a thought it is important now to capture in such material figures as that of ruination.

Thought that matters does not go alone; it is propped, blocked, and baffled by its own conditions-finite then and inevitably bound to the play of matter (which would be 
why it matters to play, why there can be no firm and graspable limit between curricular work and extracurricular play, or between the forms of argument and those of sociability). Thought "as such" does not happen, which is why now more than ever it happens only on the occasion of the objects that bind us to disciplinarity even and especially in its radical instability; it is this that demands both that we think the university and that we do so not from above it but from within it. "Theory" has played-and no doubt will continue to play-an ambivalent role here, offering both a form of rescue to the university of excellence and its professional subunits and the possibility of something other than that. This may be a reason to cultivate languages other than those of theory in attempting to speak of these things.

"English," too, with all its lately sprouting offspring, has proven an ambivalent point of reception, inviting us variously to continue or to refuse our various confusions about-our willingness or unwillingness to take on-the weight of words, which is perhaps why some us have increasingly been drawn to those sites where notions of "medium" and "discipline" comunicate in more promising ways, places where one might have to say-for example and with Lyotard, Damisch, and Rosenberg-that "paint thinks." On this route, the fate of the university seems tied, for the moment at least, to that of art. But that, clearly enough, would be another story.

It will hardly be surprising that early on Sax Gram became the object of written critique for "papering over real difference," just as it cannot be surprising that the team had moments of appreciating its activity in directly theoretical-if also parodic-terms. There was, I thought, particularly good stuff on positioning and the illicit privileging of "home" at our first (and only) annual awards banquet. It is perhaps inevitable that some of us began imagining instituting an annual Softball Lecture, and others began to dream of playing other departments with some claim to theoretical cachet or correctness.

If we were reasonably successful in not confounding playing softball and "playing hardball," we nonetheless played for keeps. We were not above unsubtle forms of physical revenge on the rudely young brutes we played, and second base had a particularly pronounced inclination to use her cleats on those who stretched the limits of legitimate sliding (indeed she sometimes seemed to wait with a certain eagerness for slides she could plausibly read as "too hard"). New recruits to the team sometimes had a problem with our tendency to 
know the rules and to argue calls, once even successfully appealing a game on the grounds of a rule violation.

The injury roster was moderately impressive: a broken finger (feminist), rib (pragmatist), and nose (medievalist); a badly sprained hand (deconstructionist); and bruises and muscle pulls (all across the range of contemporary textual study) too numerous to list. The time since has been far crueler than we could have imagined: Old Timers' Day looks unlikely, and there is in any case no one now to conjure our defeats into victory.

We liked the look of our black-and-gold shirts, and we wanted all of it to count as "service." But if it was indeed service, it was not to the department or to the profession, and certainly the university was not prepared to recognize it. It was fun, and for a time it made a difference.

Accueil Surfaces | Table des matières | Recherche $\underline{\text { Surfaces Home Page | Table of Contents | Search }}$

PUM | Livres | Revues | Publications électroniques | Vente et distribution 